\title{
Environmental Themed Dance Learning to Improve Down Syndrome Students' Cognitive Abilities With Audio Visual Media at SMK RA KARTINI
}

\author{
Sidqia Nurfadilah*, Juju Masunah, Yuliawan Kasmahidayat \\ Arts Education Study Program, Graduate School \\ Universitas Pendidikan Indonesia \\ Bandung, Indonesia \\ *sidqianurfadilah@gmail.com
}

\begin{abstract}
The aim to improve students' cognitive abilities, where researchers see when children who have Down syndrome, in dancing, children experience difficulties because they are difficult to perform dance movements and are sensitive to their environment. used is descriptive analysis with a qualitative approach. Subjects in this study were students of SMK RA Kartini in the extracurricular learning of dance, namely class $X$. Using audio visual media, data collection in the study, namely interviews, documentation, dance pre-record tests, daily notes, and observations. Analysis of the data in the study, namely the analysis of the process and the analysis of the results. The results of the study were the cognitive enhancement of Down syndrome students among them aspect intellectual, such as knowledge, understanding, and thinking skills. So that this research can improve children's cognitive abilities and show good progress for the development of thinking.
\end{abstract}

Keywords-down syndrome, environmental-themed dance, cognitive, audio-visual

\section{INTRODUCTION}

Dance learning at the vocational high school level is very important, especially children who have special needs, dance learning not only teaches body movements but can stimulate the brain to foster creativity and improve social skills how to relate to the surrounding environment, where in the learning process students are directed to be creative to communicate with their friends. , build self-confidence.

Regarding the development of student behavior at SMK RA Kartini, especially class X students in the 2019/2020 academic year, the results of a preliminary study show that in general they have characters that are at the limits of reasonableness, meaning that students in this school have personality characters that are not classified as good. also not classified as low. However, there are still students who have less personality $(20.33 \%)$. This of course needs to be the concern of all school components to be able to shape student personalities in a better direction, including fostering student social characteristics through various application of learning approaches.

The problem that arises is that there are Down syndrome children whose learning is joined by normal students. There that the child is generalized, this becomes a trigger for how the learning process of environmental-themed dance at SMK RA Kartini?

SMK is a formal education that organizes vocational education at the secondary upper secondary education level from SMP / MTS, vocational high schools (SMK) are inskuli schools while children with special needs really need more attention in terms of learning here children do not have special learning

According to L. Batshaw, nd in According to Bandi in 1992 Down syndrome, one of the children with special needs, which is a condition of underdeveloped physical and mental development in children due to abnormalities in chromosomal development, mentally disabled children generally have more abnormalities than disabilities. others, especially intelligence. Almost all cognitive abilities of mentally disabled children have abnormalities such as the ability to overcome problems, lack of ability to make a cause and effect relationship, so that their appearance is very different from other children [1].

Down syndrome, a child with special needs, which is a condition of underdeveloped physical and mental development in children caused by abnormalities in chromosome development according to L. Batshaw, nd in According to Bandi in 1992 mentally disabled children generally have more abnormalities than other disabilities, especially the intelligence. Almost all cognitive abilities of mentally handicapped children have disorders such as slow learning, ability to overcome problems, lack of ability to make causal relationships, so that their appearance is very different from other children [1].

Jean Piaget's theory [2] about cognitive development provides a return on intelligence, knowledge and the relationship of students with their environment. Intelligence is 
a continuous process that forms the necessary structures for continuous interaction with the environment. The structure that is shaped by intelligence, knowledge is highly subjective in infancy and early childhood and becomes objective in early adulthood [3].

The characteristics of Down syndrome children in the learning process that are very prominent in addition to the lack of understanding are children who get bored easily, have a short concentration span in receiving learning and act at will. They sometimes look for activities that interest them more. Most Down syndrome children will be very cheerful if invited to dance, sing, color, and do other fun activities. Providing learning material that is really interesting so that the existing potential of children can develop more optimally, children with Down syndrome have a very short concentration span in receiving learning.

Environmental-themed dance learning to improve the cognitive of Down syndrome students by using audio-visual media requires a study and implementation of the learning approach, it is hoped that it can show positive results.

\section{METHODS}

In This study uses a descriptive quantitative approach to explain a situation or a clear picture of the implementation of environmental-themed dance learning in children with Down syndrome at SMK RA Kartini through audio-visual media with the aim of improving children's cognitive.

According to Sugiyono descriptive analysis method is a statistic used to analyze data by describing or describing the collected data as it is without intending to make general conclusions or generalizations [4].

Through this descriptive research, researchers get information from various sources, by collecting data from observations, interviews, and documentation.

The data collection technique uses the method of observation, interviews and documentation that has been described by Maryono. Qualitative research data analysis techniques are inductive, meaning that all conclusions are formed from all information obtained from the field. Researchers can make solid final conclusions as a closing research report [5].

Interviews are one of the data collection techniques by directly asking questions to sources or informants related to research topics. With advances in technology, interviews can now be conducted by telephone or video call. Interviews are used when researchers want to know the experiences or opinions of informants about something in depth. Interviews can also be used to prove information or information that has been obtained previously.

Observation is a technique used to collect research data through observation and sensing. The researcher then created a report based on what he saw, heard, and felt during the observation. Observations are made to get a more real and detailed picture of an event or incident. Researchers can observe certain communities to understand their habits or ways of working. Observations can be in the form of participatory, unstructured, and group observations.

Documentation is a qualitative data collection method by viewing or analyzing document documents created by the subject himself or by others about the subject. A large number of facts and data are stored in material in the form of documentation.

A test is a deliberate action or experiment to find out how good a job is, a test is a way to check someone's knowledge or understanding.

\section{RESULTS AND DISCUSSION}

\section{A. Environmental Themed Dance Lessons Using Audio Visual Media}

Based on the results of direct observations in the field to the implementation of the training carried out, this study found 2 components that were carried out by the trainer in the process of observing students' cognitive towards environmental-themed dance in self-development activities at SMK RA Kartini, namely the dance training process and dance work.

The dance lessons that will be carried out are group dances with the theme of the environment, in which a participatory environment, which means that all school members or school components must participate and be responsible for protecting and caring for the surrounding environment. an overview of the learning process of environmental themed dance improves children's cognition, namely the teacher explains to students the understanding and knowledge of the environment which consists of the environment of human life and the environment about the existence of plants and flowers, as well as the existence of animals / animals (flora and fauna),

After the teacher gives an explanation of the existence of the environment in general, the teacher then explains that the existence of this environment can be a story in a simple dance work, all students can learn dance by imitating the movements observed by students from the environment. There is active student communication in responding to the teacher's explanation through question and answer activities. The role of the teacher in providing explanations and directions to students in the learning process in instilling understanding, and improving cognitive through students 'ability to communicate, cannot be separated from the observations of researchers. After completing learning activities, the teacher evaluates (per group) to find out students' understanding of the material given, namely knowing the environment, such as life / movement animal, the existence of flowers and plants, as well as human activities / activities.

The environment (environment) as the basis of teaching is a conditional factor that affects individual behavior and is an important learning factor. Educational learning / learning environment, consisting of the following: 
- The social environment is a community environment, whether a large group or a small group;

- Personal environment includes individuals as a person influencing other private individuals;

- The natural environment (physical) includes all natural resources that can be used as learning resources;

- The cultural environment includes the results of culture and technology that can be used as learning resources and which can be supporting factors for teaching. In this context, it includes a system of values, norms, and customs [6].

Based on the above opinion, the learning given should bring children closer to the environment, so that the education provided will be meaningful and useful for children when adapting to the environment. Furthermore, regarding the elements of environmental resources that exist in society, it is said that "A very important environmental dimension is society. In this context, society includes elements of individuals, groups, natural resources, cultural sources, value systems and norms, conditions / situations, and problems [6].

Furthermore, Sudjana and Rivai [6] stated that:

The natural environment deals with everything that is natural in nature such as geographical conditions, climate, air temperature, seasons, rainfall, flora (plants), fauna (animals), natural resources (water, forests, soil, rocks, etc. other)... by studying the natural environment, it is hoped that the students will be able to better understand the subject matter at school and be able to foster a love of nature, awareness to protect and maintain the environment as well as to preserve the ability of natural resources for human life [7].

From the explanation above, the environment that is used as a source of teaching materials is the school environment through students' observations of the nature around the school environment by finding things in nature such as animals (birds, cats, rabbits, chickens, etc.), plants (flowers, leaves). and human activities (farming and gardening). Love for the environment can not only be manifested through behavior alone, but can also be done through art, a creativity can be created by using nature as a source of inspiration in making a themed dance. Themed dance is a dance movement that is lifted from a story or tells an experience or event, for example events about human behavior, animal behavior or natural events

Listening from the opinions above, it can be concluded that this environmental-themed dance learning is learning that comes from the surrounding environment where students do activities such as in the neighborhood where they live and the sexual school environment where they study. Environmentalthemed learning in growing students' interpersonal intelligence is expected to be able to train students to socialize with other friends, learn to respect themselves and the opinions of others (friends). Students are active and creative and sensitive to the environment around them.
The teacher as a facilitator directs students to interact more with their surroundings. Environmental dance learning is carried out through observation and imitation of the environment such as plants, animals and human activities. Based on this, in learning environmental-themed dance there are values that can be adapted by students, such as students being able to keep their environment clean, students also understanding and loving every creature created by God Almighty in their surroundings such as plants, animals, and human activities around them. such as gardening, farming etc. In the learning process students do not only explore the movements of what they observe,

\section{B. Characteristics of Down Syndrome Children in Environmental Themed Dance}

The learning outcomes of environmental themed dance given to class X students at SMK RA Kartini are basically able to achieve the expected goals, where students can move what dance is in the surrounding environment

However, the most important thing that is expected to be achieved in the learning process of environmentally themed dance is to increase his love for the environment and sensitivity to the environment.

Based on the results of this study, it appears that students are able to improve the learning process to think, reason, solve problems to remember well. Although there are some children who are still a bit slow to take part in this dance lesson, students show very significant progress after listening to audio visuals and matching what music they need to move. Overall, from the results of this learning, the child shows good progress.

\section{CONCLUSION}

Environmental-themed dance learning uses audio visual media provided to Down syndrome students with the aim of increasing intellectual thinking skills so that students are more sensitive to the surrounding environment and increase their love for the environment, with dance movements based on what is seen every day and simple movements.

Overall it can be said that through the implementation of environmental-themed dance with audio-visual media improves cognitive well, it can be seen from the ability of students to learn to think, reason, solve problems to remember well.

\section{ACKNOWLEDGMENT}

The research process and the compilation of the results received support from the Postgraduate School of the Indonesian University of Education.

\section{REFERENCES}

[1] L. M. Batshaw, (nd). Children with Disabilitis.

[2] P. Suparno, Teori Perkembangan Kognitif Jean Piaget. Yogyakarta, 2011. 
[3] F.H. Kawanto and S. Soedjatmiko. "Development Monitoring of Children with Down Syndrome." Sari Pediatri 9, no. 3. 185-90. 2016.

[4] Sugiyono, Educational Research Methods with Quantitative Approaches, Qualitative, and R \& D. Bandung: Alfabeta, 2014
[5] Maryono, Basics \& Techniques to become an Education Supervisor. Yogyakarta: Ar.Ruzz Media, 2011.

[6] A. Rivai, N. Sudjana, Teaching Media. Bandung: Sinar Baru Algensindo, 2009.

[7] C. Chaplin, Kamus Psikologi (Terjemahan). Jakarta: Erlangga, 1991. 